\title{
Income Increase of Farmers Through Utilization of Acacia Logging Residues For Wood Chips
}

\author{
Elisa Wildayana* \\ Socio-Economic Department of Agriculture, Faculty of Agriculture, Sriwijaya University, \\ Raya Palembang Street-Prabumulih KM 32 Indralaya Campus, South Sumatra (30662), Indonesia
}

Diterima: 12 Mei 2016; Direvisi: 30 Mei 2016; Disetujui: 5 September 2016

\begin{abstract}
The research aimed to examine feasibility of acacia logging residues and to increase farmers' income through utilization of acacia logging residues for wood chips. The research was conducted in District of Ogan Komering Ilir (OKI), South Sumatra. This research was a case study and the analysis unit is chips mills development at Village Unit Cooperatives. Data was collected through questionnaires, in-depth interview, observation and desk study. The research resulted that Scenario 1 is the best priority in terms of its effectiveness in reducing operating costs followed by Scenario 2 and Scenario 3 because Scenario 1 can produce maximum income compared to other Scenarios. Financial feasibility of present conditions is compared to Scenario 2 because chips mills in Scenario 2 utilized also $100 \%$ acacia logs. Present condition means that acacia logs are transported directly to HTI Company of chips mills and fully managed by the HTI Company. This comparison shows that Scenario 2 is less profitable compared with those on the present condition. To gain high income, it is recommended if Scenario 1 is applied which utilize $100 \%$ of acacia logging residues for making chips mills with B/C 35.47, NPV Rp 80,674.50 Mills, IRR $670.29 \%$ and BEP at 4,704.65 tons/year. Another alternative can be applied for Scenario 3 by using raw materials with a combination of acacia $\operatorname{logs}(50 \%)$ and acacia logging residues $(50 \%)$ with B/C 20.45; NPV Rp 45,418.52 Mills and IRR 394.70 \% with BEP at 7,989.52 tons/year.
\end{abstract}

Keywords: acacia; feasibility, residues; utilization; wetlands

\section{Introduction}

There are a number of uses for acacia forest residues generated by various activities (namely operations of logging, milling, etc.) such as in the manufacture of wood chips, fuel pellets, particle board, oriented strand board, mulch and others. Forest residues come from a number of different sources including slash and lumber mills. In addition, there is a demonstrated decrease in the amount of forest residue being generated (Armanto and Wildayana, 1998, Wildayana, 2006a, 200b).

The species of the forest slash commonly found in HTI in South Sumatra wetlands is Acacia $s p$. Recent estimates indicate that 50-75 $\%$ of the forest slash comes from Acacia $s p$ logging. Therefore, the most promising (i.e., utilizing the greatest quantities) acacia residue use seems to be in the manufacturing of wood chips especially for home industry and groups of cooperative local people (Benjamin et al., 2009,

\footnotetext{
${ }^{*}$ Penulis Korespondensi.

E-mail: wildayana.elisa@yahoo.com

Telp: +62-711-820933, HP: +62-8127338950
}

Nati et al., 2010, Tahvanainen and Anttil, 2011). Acacia wood chips is the main raw material of paper making, molding, charcoal, medium density fiber board, particle board and household crafts (Dirkswager et al., 2011). Chips required for the manufacture of paper pulp is increasing in connecting with the rapid development of wood and paper industry, will affect directly the needs of raw materials in the form of chips. Assuming that to produce one ton of pulp takes $4.50 \mathrm{~m}^{3}$ of chips and if there are $187 \mathrm{~m}^{3} /$ ha of forest products, then in 1 ha of land can produce 41.56 tons of pulp (Valente et al., 2011).

Selection of the form of raw material or processed material is dependent upon the cost of transportation of raw materials to the location of the pulp and paper plan and chips price in the fields. If acacia logging residues for wood chips are utilized and processed in the form of chips, it is expected to minimize amount of waste (no waste), to create environmentally social forestry management and to generate the improvement of farmer's income. Others benefits are as follows: to minimize burning of acacia forest residues, but rather utilized, thus smoke will be not produced, 
to support the preservation of environmental functions by optimizing the use of available forest resources, and to provide job opportunities, increase income and welfare of the local community.

The successful factors of acacia logging residues (waste) utilization include a beneficial use, an adequate market, and an economical, profit-making process and others. Many utilization processes would be satisfactory if they caused the overall cost of logging residues management to be less than that of disposal. Any additional steps in waste utilization should repay the extra storage, processing, and distribution costs that are incurred from that utilization. Several basic steps must be taken when considering waste utilization possibilities, namely to identify clear goal or need, to identify constraints and needed encouragement, to determine waste availability and characteristics, to select appropriate utilization technology, to identify capabilities of individuals who will operate the utilization process and use the resultant product, to determine market for resultant product and to identify the economics of utilizing forest waste into the manufacturing of a commercial product.

Wood chips made from homogenous raw material of Acacia will produce good quality of pulp with particular specifications, namely the extractive levels are not too high if the extractive levels too high, it can lead to increase consumption of cooking chemicals during the pulping process, the homogenous size of chips ( $25 \mathrm{~mm} \times 25 \mathrm{~mm} \times 4 \mathrm{~mm}$ ), if its size is larger, thus its ability to penetrate the cooking liquid is reduced and uneven, and the pulp produced is not uniform, and mass density is appropriated to the pulping process used. Therefore this research aimed to examine the utilization feasibility of acacia logging residues in the production of commercial wood chips and to increase farmer's income through utilization of acacia logging residues for wood chips in South Sumatra wetlands.

\section{Research Methods}

\subsection{Time and Research Site}

The research has been conducted in District of Ogan Komering Ilir (OKI), South Sumatra Province which has a production forest area of around 645,249 ha. The research area is degraded peat swamp ecosystem that is sensitive to wildfire (Armanto and Wildayana, 1998).
Before it was degraded, the area belonged to primary forest where the logs are utilized with the Permission of Forest Concession Right $(\mathrm{HPH})$, however its management is not sustainable. Post concession period, three companies of Industrial Plantation Forest (HTI) were surveyed and sampled, namely PT. SBA (covering an area of 142,235 ha), PT. BMH (around 250,370 ha) and PT. BAP (192 700 ha). Total of all concessions covered around 585,305 ha or $90.71 \%$ of the total production forest of acacia wood (Asmani, 2011).

\subsection{Research Procedure}

This research used a case study method, the unit of analysis is chips mills development at Village Unit Cooperatives (KUD) or home industry level. In general, acacia wood waste can be grouped into three major sections, namely the remains of the wooden twigs, residues of branches, and leftover pieces of wood logs (wood waste). Further financial analysis will be done to examine the feasibility through utilization of acacia logging waste for commercial chips in wetlands. Financial aspect will be to discuss the costs (comprising the cost of investment and operational cost) and benefit obtained by farmers (including revenue and income). Decisions investment will further consider the micro policy (among other tax, retribution and incentives), inflation (including selling prices, input price and interest rate) and financial parameters (among others net $\mathrm{B} / \mathrm{C}$ ratio, NPV, IRR, BEP and sensitivity analyses).

\subsection{Data Analyses}

Data collection was carried out through interview guide using questionnaires, in-depth interview, observation and desk study. The collected data were processed using Windows Excel spread sheet program. The results are tabulated and described in the descriptive quantitative. The research flow chart is presented in Figure 1. To determine Scenarios of chips mills, the most financially feasible scenario is calculated and analyzed by using the following formula:

\section{a. Net Present Value (NPV)}

NPV $=$ PV Benefit - PV Cost.

Where :

NPV $=$ Net Present Value

PV Benefit $=$ discount factor $\mathrm{x}$ Benefit

PV Cost $=$ discount factor $x$ Cost 
b. Calculation of Gross Benefit Cost Ratio (Gross B/C)

GrossB/C $=\frac{\sum \text { PV Gross Benefits }}{\sum \text { PV GrossCosts }}$

The business is said to be feasible and provide benefits if the value of $\mathrm{B} / \mathrm{C}$ is greater than 0 .

c. Internal Rate of Return (IRR)

$\mathrm{IRR}=\mathrm{i}_{1}+\frac{N P V_{1}}{N P V_{1}-N P V_{2}}\left(\mathrm{i}_{2}-\mathrm{i}_{1}\right)$

Where:

$\mathrm{i}_{1}=$ the highest discount factor that still gives positive NPV

$\mathrm{i}_{2}=$ the lowest discount factor that still gives negative NPV

$\mathrm{NPV}_{1}=$ Net Present Value Positive

$\mathrm{NPV}_{2}=$ Net Present Value Negative

If the NPV calculation generates that NPV value $=0$, it means that at the discount rate used, the project will restore the capital utilized, but it does not produce any surplus. IRR of the project is the discount rate to achieve NPV $=0$. If the IRR is higher than the interest rate or the rate of loan capital or opportunity cost of capital, then it can be said that the project is a profitable investment.

d. Break Event Point (BEP):

$\mathrm{BEP}=\frac{F C}{H y-V C}$

Where:

BEP = Break Event Point of production (Unit)

$\mathrm{FC}=$ Fixed cost or investment (Rp)

$\mathrm{VC}=$ Variable or operational cost $(\mathrm{Rp} / \mathrm{Unit})$

Hy = Selling price $(\mathrm{Rp} /$ Unit $)$

\section{Results and Discussion}

\subsection{Acacia Forest Slash or Logging Residues}

Acacia logging residues of HTI (Industrial Plantation Forest) consist of portions of the trees which are found on the forest floor or the forest soil surface after logging operations happened. Logging of acacia forest mostly consists of tree branches, tops of trunks, stumps, branches and leaves. Other wood sources are from stand improvement (rough and rotten trees, cull trees or dead trees, small-sized trees, non-commercial tree species removed from woodlots, and trees from thinning carried on growing stock). The various residues of acacia are classified as logging tops, culls and pre-commercial thinning of acacia forest.

Logging Tops belong to the unmarketable upper portion of the stem. The top is typically a stick about $0.70-3.40 \mathrm{~m}$ in length with a diameter of $5.40-15.00 \mathrm{~cm}$ at the base. Biomass left in fields after harvesting reached 15.24 tons/ha/year which consist of twigs and branches of acacia wood and leaves. Such left biomass in the fields can be used as raw materials for making of wood chips by local farmers.

Culls are the portion of annual growth of acacia wood harvest belonging broken, cut and left in the acacia forest. The culls of acacia tree contains a minimum of $5-25 \%$ of marketable acacia. Sorting of acacia wood is due to defective, rotten or unwanted species of acacia.

Pre-commercial Thinning are the residue material that comes from timber stand improvement. They are generally round and densely stocked stands. Cultivated acacia trees produce a lot of litters which in the long term can be decomposed into soil organic matter. The average litters of fallen acacia foliage and undergrowth reached 3.85 tons/ha/year.

In addition, farmers also planted acacia trees in their house yards and their gardens and their biomass was estimated around 20.50 ton/ha/year. The total biomass of acacia woods not managed by the company HTI are around 35.74 tons/ha/year. If acacia wood and wood waste is not used effectively, efficiently and sustainably, then this would potentially be biomass fuels to happen potential land and forest wildfires. Volume of acacia logging residues biomass at the research area are presented in Table 1.

Table 1. Biomass volume of acacia logging residues in the research area

\begin{tabular}{llc}
\hline No. & $\begin{array}{l}\text { Source of acacia logging } \\
\text { residues }\end{array}$ & $\begin{array}{c}\text { Volume } \\
\text { (tons/ha/year) }\end{array}$ \\
\hline 1. & $\begin{array}{l}\text { Logging tops consist of upper } \\
\text { portion of the stem, twigs and } \\
\text { branches of acacia wood } \\
\text { (Biomass left in fields after }\end{array}$ & 15.24 \\
& harvesting) & \\
2. & Acacia logs owned by farmers & 20.50 \\
\hline & Total & 35.74 \\
\hline
\end{tabular}

Source : Field calculation (2015).

A very large amount of wood remains a potential that needs to be developed. Therefore, to convert this opportunity into a reality, then some important things need to be considered, 
especially for the processing of wood into chips, among others, as follows: continuity of procurement of raw materials to be used as chips, the distance logging into wood working, the means of communication and means of transportation available to and from the location of the processing or manufacture of chips (including roads and means of transport), the economies of scale of business to be conducted, marketing product, government regulations relating to the use of wood residues and low population density and labor requirements.

Fortunately most of above requirements can be fulfilled by the research area, except Government regulations relating to the use of wood residues. Then the amount of concession opportunities will be excusable and without any further research, this concession opportunities remain as a potential only. On the basis of the above challenges, there should be a comprehensive review of the potential favorable change of companies and local Government.

\subsection{Financial Feasibility Analysis}

Financial feasibility analysis of chips mills focuses on the determination of raw materials cost (derived from wood logs or acacia logging residues with the different price of each raw materials). To find some alternatives which provide the lowest capital costs and the highest income levels of farmers, then three main Scenario are studied and analyzed, namely:

Scenario 1 is defined as an alternative in which the operation of the chips mill using raw materials derived entirely acacia logging residues $(100 \%)$ with the price of USD $34,850 / \mathrm{m}^{3}$, for a total of acacia wood raw material of $241,691 \mathrm{~m}^{3}$ for the purposes of production capacity chips of 40,000 tons/year of filtered dry chips.

Scenario 2 is used an alternative in which the operation of the chips mills using raw materials derived from whole logs acacia $(100 \%)$ for Rp $185,000 / \mathrm{m}^{3}$, for a total of acacia wood raw materials for the purposes of $241,690.82 \mathrm{~m}^{3}$ chips production capacity of 40,000 tons/year of filtered dry chips.

Scenario 3 is determined as an alternative in which the operation of the chips mills using raw materials with a combination of acacia logs (50\%) for $\mathrm{Rp} 185,000 / \mathrm{m}^{3}$ and acacia logging residues $\left(50 \%\right.$ ) for USD $34,850 / \mathrm{m}^{3}$, of the total material acacia wood raw material for the purposes of 241,690.82 $\mathrm{m}^{3}$ chips production capacity of 40,000 tons/year of filtered dry chips.

It is calculated how much costs for each scenario. Investment costs are not influenced by differences and combination use of raw materials. What has to be taken into account is a component of operating or variable costs. The calculation results of production costs (investment and operational) and financial feasibility analysis for all scenarios are presented in Table 2 and Table 3.

The investment cost and the selling price of chips looked like for all Scenarios. Net income of Scenario 1 showed the highest value due to the lowest operating costs of Scenario 1. This low operating costs in Scenario 1 is caused that raw materials for chips mills utilizes acacia logging residues where the price of acacia logging residues was much lower than the price of acacia logs. Scenario 2 generated the lowest net income due to the highest operational costs (high price of acacia logs).

Table 2. Financial feasibility analysis of chips mills in the District of OKI*/

\begin{tabular}{|c|c|c|c|}
\hline Component details & Scenario 1 & Scenario 2 & Scenario 3 \\
\hline Investment costs (Mills Rp) & $5,190.69$ & $5,190.69$ & $5,190.69$ \\
\hline Operating costs (Mills Rp/year) & $11,667.54$ & $47,957.40$ & $29,812.47$ \\
\hline Income after taxes, $1^{\text {st }}$ year (Mills Rp/year) & $39,719.21$ & $7,058.34$ & $23,388.78$ \\
\hline ¿NPV B Positive (Mills Rp) & $210,198.36$ & $32,165.60$ & $121,181.98$ \\
\hline$\Sigma$ NPV B Negative (Mills Rp) & $69,950.81$ & $267,764.98$ & $168,857.89$ \\
\hline NPV (Mills Rp) & $80,674.50$ & $10,162.54$ & $45,418.52$ \\
\hline Net B/C & 35.47 & 5.43 & 20.45 \\
\hline $\operatorname{IRR}(\%)$ & 670,29 & 119,10 & 394,70 \\
\hline BEP (tons/year) & $4,704.65$ & $26,474.36$ & $7,989.52$ \\
\hline
\end{tabular}

Explanations $\quad: * /$ Selling prices of filtered dry chips was determined Rp 1.40 Mills/ton and Expected Rate of Return was 18\%

Source $\quad$ : Field observation and calculations (2015). 
NPV (Net Present Value) was calculated at a discount rate of $18 \%$ for 24 years. NPV for all scenarios showed positive value, it means that each scenario of chips mills operations is feasible and can be operated. However the highest NPV ( $\mathrm{Rp} \mathrm{80,674.50} \mathrm{Mills)} \mathrm{is} \mathrm{indicated} \mathrm{by} \mathrm{Scenario} 1$ (100\% raw material of Acacia logging residues) and it is followed by Scenario 3 ( $R p$ 45,418.52 Mills) and Scenario 2 (Rp 10,162.54 Mills).

Net B/C (Benefit Cost Ratio) is calculated at basis of a value discount of $18 \%$. This discount rate is based on the value of the investment bank interest for the industrial sector. All scenarios are feasible where the value of Net $\mathrm{B} / \mathrm{C}$ is $\geq 1$. The most profitable and financially most feasible is Scenario 3 with net B/C of 35.47. Scenario 1 is greater than Scenario $2(84.69 \%)$ and $(42.35 \%)$ greater than Scenario 3, while Scenario 2 is $276.61 \%$ smaller than Scenario 3. So priority order is recommended for Scenario 3, followed by Scenario 2 and Scenario 3.

IRR (Internal Rate of Return) for all Scenarios are far beyond the value of the expected rate of return, i.e. respectively by $670.29 \%$ for Scenario 1, IRR for Scenario 2 is $119.10 \%$ and $394.70 \%$ for Scenario 3. Scenario 1 is the most prospective for chips mills development because it will provide the highest return on capital the by a margin of $82.23 \%$ to $41.14 \%$ of Scenario 2 and Scenario 3.

Table 3. Comparison of financial feasibility analysis among Scenarios

\begin{tabular}{lccc}
\hline \multirow{2}{*}{ Component details } & \multicolumn{3}{c}{ Differences among Scenarios */ } \\
\cline { 2 - 4 } & S1 with S2 (\%) & S1 with 3 (\%) & S2 with S3 (\%) \\
\hline Operating costs & -311.05 & -155.52 & 37.84 \\
Income after taxes, $1^{\text {st }}$ year & 82.23 & 41.12 & -231.37 \\
NPV & 87.40 & 43.70 & -346.94 \\
Net B/C & 84.69 & 42.35 & -276.61 \\
IRR & 82.23 & 41.12 & -231.09 \\
BEP & -462.73 & -69.83 & 69.82 \\
Feasibility priority & 1 & 3 & 2 \\
\hline
\end{tabular}

Explanations : */ S1 (Scenario 1), S2 (Scenario 2), S3 (Scenario 3)

Source $\quad$ : Field observation and calculations (2015)

BEP (Break Even Points) for Scenario 3 is reached if chips production is around 7,989.52 tons/year. BEP of production at the lowest value is for Scenario 1 (4,704.65 tons/ha), this means that Scenario 1 produces the fastest Expected Rate of Return. BEP of Scenario 2 are the worst among all scenarios because production capacity of chips mills has to achieve a minimum value of 26,474.36 tons/year. By obtaining the value of BEP, then farmers can determine how large the scale of chips mills operation that can produce the Expected Rate of Return quicker. If information about the operations scale can be clearly known, it is possible there will be an increase in the flow of investment and opportunities to expand.

By considering of Net B/C, NPV, IRR and BEP values for chips mills, financially it can be concluded that chips mills in all Scenarios are suitable to be conducted in the fields. However, Scenario 1 is very high beyond the value of the expected rate of return $(18 \%)$. Therefore, financially Scenario 1 is very feasible. It is concluded that Scenario 1 is the best priority in terms of its effectiveness in reducing operating costs followed by Scenario 2 and Scenario 3 because Scenario 1 can produce maximum income compared to other Scenarios.

\subsection{Comparison of Chips Mills Scenarios with Present Conditions}

Financial feasibility of present conditions is compared to Scenario 2 because chips mills in Scenario 2 utilized also $100 \%$ acacia logs. Present condition means that acacia logs are transported directly to HTI company chips mills and fully managed by the HTI Company (Table $4)$.

$\mathrm{B} / \mathrm{C}$, NPV and IRR on present condition is greater than those values of Scenario 2 . The $\mathrm{B} / \mathrm{C}$, NPV and IRR of present condition is $8.61, \mathrm{Rp}$ 12,361.27 Mills and $176.00 \%$ respectively while those values in Scenario 2 is 5.43, Rp 10,162.54 Mills and 119.10 respectively. BEP of Scenario 2 (26,474.36 tons/year) is greater than the value of $\mathrm{BEP}$ in the present conditions $(20,410.64$ tons/year), meaning that BEP on the present condition can faster than those on Scenario 2. In other words this comparison shows that Scenario 2 is less profitable compared with those on the present condition. 
In order to be able to gain high income, it will be recommended if Scenario 1 is applied which utilize $100 \%$ of acacia logging residues for making chips mills with $\mathrm{B} / \mathrm{C}$ around 35.47 , NPV Rp 80,674.50 Mills, IRR 670.29\% and $\mathrm{BEP}$ at 4,704.65 tons/year. Another alternative can be applied for Scenario 3 by using raw materials with a combination of acacia $\operatorname{logs}(50$ $\%)$ and acacia logging residues (50\%) with $\mathrm{B} / \mathrm{C}$ around 20.45, NPV around Rp 45,418.52 Mills and IRR of $394.70 \%$ with BEP at 7,989.52 tons/year.

\section{Conclusions}

Scenario 1 is the best priority alternative in terms of its effectiveness in reducing operating costs followed by Scenario 2 and Scenario 3 because Scenario 1 can produce maximum income compared to other Scenarios. Financial feasibility of present conditions is compared to Scenario 2 because chips mills in Scenario 2 utilized also $100 \%$ acacia logs. Present condition means that acacia logs are transported directly to HTI company chips mills and fully managed by the HTI Company. In other words this comparison shows that Scenario 2 is less profitable compared with those on the present condition.

\section{Acknowledgements}

The authors wish to acknowledge the supports provided by Sriwijaya University and the author's thanks are also directed to the Faculty of Agriculture, Sriwijaya University for allowing us to use the research facilities.

Table 4. Comparison of chips mills feasibility with present condition

\begin{tabular}{lcccc}
\hline \multicolumn{1}{c}{$\begin{array}{c}\text { Economic } \\
\text { parameters }\end{array}$} & \multicolumn{3}{c}{ Chips mills } & Present condition */ \\
\cline { 2 - 4 } Scenario 1 & Scenario 2 & Scenario 3 & \\
\hline B/C & 35.47 & 5.43 & 20.45 & 8.61 \\
NPV (Mills Rp) & $80,674.50$ & $10,162.54$ & $45,418.52$ & $12,361.27$ \\
IRR (\%) & 670.29 & 119.10 & 394.70 & 176.00 \\
BEP (ton/year) & $4,704.65$ & $26,474.36$ & $7,989.52$ & $20,410.64$ \\
\hline
\end{tabular}

Explanation : */ Acacia logs are transported directly to HTI company chips mills

Source $\quad$ : Field observation and calculations (2015)

\section{References}

Armanto, M.E. and Wildayana, E. 1998. Analyses of Land and Forest Fire Problems in Agriculture Development in Broad Meaning. Journal of Environment and Development, Vol. 18(4): 304-318. ISSN. 0216-2717.

Asmani, N. 2011. Peran Hutan Tanaman dalam Penyerapan Emisi Karbon Dioksida dan Manfaat HTI bagi Masyarakat. Disertasi. Pascasarjana Universitas Sriwijaya, Palembang.

Benjamin, J., Lilieholm, R.J. and Damery, D. 2009. Challenges and Opportunities for the Northeastern Forest Bioindustry. Journal of Forestry, Vol 107(3): 125-131.

Direktorat Rawa dan Pantai. 2009. Potensi dan Tantangan Pengembangan Rawa Indonesia. Makalah pada Seminar Lokakarya Pengelolaan
Rawa dalam Mendukung Ketahanan Pangan Nasional. Departemen Pekerjaan Umum. Hotel Nikko Jakarta.

Dirkswager, A.L., Kilgore, M.A., Becker, D.R., Blinn, C., and Ek, A. 2011. Logging Business Practices and Perspectives on Harvesting Forest Residues for Energy: A Minnesota Case Study. Northern Journal of Applied Forestry, Vol 28(1): 41-46.

Nati, C., Spinelli, R., and Fabbri, P. 2010. Wood chips size distribution in relation to blade wear and screen use. Biomass and Bioenergy, Vol 34(5): 583-587.

Tahvanainen, T., and Anttil, P. 2011. Supply chain cost analysis of long-distance transportation of energy wood in 
Finland. Biomass and Bioenergy, Vol 35(8): 3360-3375.

Valente, C., Spinelli, R., and Hillring, B.G. 2011. LCA of environmental and socio-economic impacts related to wood energy production in alpine conditions: Valle di Fiemme (Italy). Journal of Cleaner Production, Vol 19(17-18); 1931-1938.

Wildayana, E. 2006a. Dampak Kebakaran Hutan dan Lahan Terhadap Sosial Ekonomi Masyarakat di Propinsi Sumatera Selatan. Jurnal Ilmiah HABITAT, Vol XVII(3): 218-227, September 2006, ISSN. 0853-5167.

Wildayana, E. 2006b. Rancang Bangun Program Kerja Wanita Tani sebagai Sumber Nafkah pada Sistem Usahatani Terpadu. Jurnal Ilmiah HABITAT, Vol XVII(4): 279-292, Desember 2006, ISSN. 0853-5167. 